\title{
POGLĄDY JOZEFOLOGICZNE ŚW. EFREMA I DIONIZEGO BAR SALIBI
}

\author{
I. JÓZEFOLOGIA SW. EFREMA
}

Swięty Efren/306-373/, zwany doktorem maryjnym, pozostawił nam również pewną naukę o św. Józefie, która jednak nie jest aź tak rozwinięta, jak jego doktryna mariologiczna ${ }^{1}$. Zawarta jest ona głównie w jego wypowiedziach o Maryi, zwłaszcza w takich dziełach jak: "Komentarz do Diatessaronu", "Hymny o Narodzeniu", "Hymny o Kościele", "Hymny o wierze", "Hymny przeciw herezjom" 1 "Pieśni Nisibijskie". Do poruszanych tam problemów józefologicznych należą: ojcostwo, genealogia, zaręczyny, relacje do Mary1, kapłaństwo 1 sprawiedlimość.

1. $0 \mathrm{j}$ c o s t $\mathrm{w}$. W jednym z hymnów o Narodzeniu Efrem uczy o Józefie, że "został nazwany ojcem prawdziwego Syna z dobroci" ${ }^{2}$. Jego jednak ojcostwo względem Jezusa nie ma charakteru naturalnego, ale tylko prawny, co potwierdzaja następujące wypowiedzi: "gdy adoptowany Syn ludzki objawił sie /.../" . "Twoje imię dało Józefowi moc, by stał się dla Ciebie 0jcem" ${ }^{4}$.

2. G e $n$ e a 1 o $i$ a. Komentując Ewangelie zajął się też problemew genealogii Jezusa ${ }^{5}$, zwracając uwage, iż Mateusz wyprowadza ją w sposób zstępujący od Adana, Lukasz zaś przeciwnie, w sposób wstępujący do Adama. Laznacza ponadto, ze Lukasz nie pisał genealogii Maryi,lecz zwracał uwagé na znaczenie tego, który był godny stać się

1 Por. I. Ortiz de Urbina, Maryja w patrystyce syryjskiej, "Częstochowskie Studia Teologiczne" 11/1983/, 95-171.

2 Hymi de Nativitate $2,6, \operatorname{CSC} 0187,13$.

3 Tamze, 2, 16, $\operatorname{Csc} 0187,15$.

4 Tamże, 27, 5, usco $187,126$.

5 Comentarii in Diatessaron 1, 26, $\mathrm{SCh}, 121,59$. 
Sługą ekonomii zbawienia i nazywać się mężem Maryi: by on z pokolenla Dawida $i$ pochodził z tej linil, do której należała Maryja ${ }^{6}$.

3. $\mathrm{z}$ a $\mathrm{r}$ e c z y $\mathrm{n}$ y J ó $z$ e $\mathbf{f}$ a. Józef według Efrema został zaręczony z Dziewicą: "Zaręczonym Dziewicy byì Józef /... Józef uczcil Dziewicę" 7 . Pyta on jednak o konieczność tych zaręczyn: "Dlaczego było konieczne, by córka Dawida została zaręczona z Józefem 1 dlaczego narodziny te odbyły się z niej bez udziału mężczyzny?"8, na co z kolei odpowiada stwierdzając: "Józef, syn Dawida poślubił córkę Dawida, ponieważ dziecko nie mogło nosić imienia matki"9 . Jezus bez udziału "oblubieńca" stał się synem Maryi" ${ }^{10}$ opisuje on następnie okoliczności tych zaręczyn wkładając w usta Maryi słowa: "Zaślubili mnie sprawiedliwenu Józefowi. Mąż przyszedł do mnie przynosząc wiadomość, pozdrowił mnie, a ja przyjęłam jego pozdrowienie ${ }^{11}$.

4. S y $n$ J ó $z$ e $\mathbf{f}$ a. Doktor z Edessy wielokrotnie podkré́lał, że Jezus jest synem Józefa, ale bez jego fizycznego udziału: "Synu Józefa, nie jestés jego nasieniem"12. Jezus uchodzi tylko za syna Józefa, podobnie jak za syna Dawida czy Maryi: "Jesteś synem Boga, syrem człowieczym, synem Józefa, synem Dawida $i$ synem Maryi"13. Z drugiej jednak strony posługując się paralelizmem antytetycznym podkreśla wyróżnienie Józefa jako prawnego ojea Jezusa: "Jestés synem Żyjącego 1 synem śmiertelnika, jesteś synem naszego Stwórcy a także Synem Józefa"14/... "0 Synu Stwórcy, Synu cies11, w domu cieśli każdego dnia myślałeś o krzyżu"15.

5. J ó z e $\mathbf{P}$ a $M$ a $r$ y $j$ a. Na kanwie bogatej Efremowej mariologii ukazana jest równieź postać św. Józefa w jego relacji do

6 Commentarid in Diatessaron 1, 26, SCh, 121, 59.

7 ifymni de Ecclesia 44, 13, CSCo 199, 107.

8 Hymni de Nativitate 2, 12, CSCO 187, 14-15.

9 Hymni de Nativitate 2, 13, CSCO 187, 15.

10 Tanże.

11 Sancti sphraemi Syri hymni et sermones 16, 7, ed. 'f. Lamy, t. 2, Mechliniae 1902.

12 Iymni de Nativitate 6, 1, CSCo 187, 43.

13 Tamze, 6, 2, CSCo $187,43$.

14 Ifymni de Fide, 17, 9, $\operatorname{Csco} 155,52-53$.

15 Tamże, 17, 11, CSCo 155, 53. 
Maryi, głównie w oparciu o dane biblijne. Komentując na przykład trudności Józefa w przyjęciu Maryi do swego domu /Mt 1, 19/ pisał: "On mimo jej ciąży zachowywał sie spokojnie, nie chciał w swej sprawiedliwości ani zniesławiać jej publicznie, ani akceptować dłużej istnienia małżéstwa myśląc, że połączyła się z kimś innym. W swej sprawiedliwoścl postanowił ani jej nie brać, ani nie zniesławiaćl ${ }^{16}$. W rozwikłaniu tej trudności przychodzi Józefowi z pomocą anioł / Mt 1, 20/: "Nie bój się przyjąć Maryi, twej małżonki". Efrem tak komentuje te słowa: "Jeżeli wątpisz w poczęcie Dzlewicy bez cielesnego zwląku, to posłuchaj słów Izajasza /7, 14/: "Oto dziewica porodzi" 1 słów Daniela /2, 34/: "Skała oderwała sie bez ponocy rąk"17.

Diakon z Edessy zwalcza zdanie głoszące, ze Maryja była małzonką Józefa dopiero po narodzeniu Jezusa:

"Jakże byłoby to możliwe, aby ta, która była mieszkaniem Ducha Św., którą potęga'Boża okryła swoim cieniem, stała się kobietą śmiertelnika i weszła w świat boleści wedle pierwotnego przekleństwa / Rdz 3, 16/. To właśnie przez Maryję, "błogosławioną niędzy niewiastami" miało zostać zniesione przekleństwo wypowiedzlane na początku czasów. Jak Zbawiciel wszedł przez drzwi zamknięte, w ten teź sposób sam wyszedł z łona dziewiczego, ponieważ ta dziewica porodziła rzeczywiście 1 prawdziwie bez boleści"18.

Oryginalna myśla Efrema było wyjaśnienie, jak Józef i Maryja mieszkali w świętości:

"Jak to rozumieć: "On ją przyjął i zamieszkał z nią w świętości"/Mt 1, 24/? Lecz jeżeli "ją przyjął", to Pismo fw. chce powiedzieć, że po poczeciu moźna gó było nazywać jej mężem. Słowa: "Zamieszkał z nią w świętości" można także rozumieć w tyın sensie, że patrząc na nią, nigdy jej nieopanowaną pożądliwością nie pożadał. "Aż wydała na świat swego pierworodnego". Wierzacy rozpoznali, ze narodzenie syna pierworodnego nie odbyło sie według praw natury ludzkiej, lecz było boskie. "On zamieszkał z nią w świętości". Była to świętóćc konieczna, chociaz ich wola w tym współdziatał a 19 .

16 Comentari1 in Diatessaron 2, 1, SCh 121, 65.

17 Tainze, 2, 3, SCh 121, 67.

18 Tamze, 2, 6, SCh $121,69$.

19 Tamze, 2, 9-10, SCh 121, 71 . 
Zamieszkiwanie w świętości dotyczyło zdaniem naszego Diakona, równie: okresu po narodzeniu Jezusa. Wyjaśnia to analizując wyrażenie "az do", które, podobnie jak wypowiedziach starotestamentalnych, nie oznacza końca ${ }^{20}$.

$$
\text { 6. S p r a w } \mathrm{i} \text { e d } \mathrm{l} i \mathrm{i} \text { o ś é J ó } z \text { e } \mathrm{f} \text { a. Ewangeliczny }
$$

przymiot Józefa "sprawiedliwy" także nie uszedł uwadze Errema, który tak go wyjaśnia w "Komentarzu do Diatessaronu": "Józel był sprawiedliwy w tym, że nie zniesławił Maryi" / Mit 1, 19/21. Po tym stwier.. dzeniu szczegółowo wyjaśnia ten przymiot w świetle zwyczajów żdowskich:
"Ponieważ Józef był człowiekiem sprawiedliwym nie chciał zniestawić publicznie Maryi, ale jego spra- wiedliwość była sprzeczna z prawem: "Twoja ręka będzie pierwsza do ukamienowania - mówi Mojzesz"/P任 22,24/. Czy Józep rozumiał, ze to poczęcie było jedyne, nie podlega zwyczajnym prawom zycia i poczęc1om, które sq owocem małżeństwa? Wszystkie te znaki zmuszały do uznania, że ta rzecz pochodzi od Boga. Nigdy nie do- puszczał u niej nawet chęci nieskromnego czynu. Co więcej, nie mógłby nie wierzyć Maryi, ponienaż było zbyt wiele dowodów na jej korzyść: utrata mowy Zacharia- sza, poczęcie Elzbiety, zapowiedź anioła, radość Jana 1 proroctwo jego rodziców. Tszystkie te rzeczy zapowia- dały donośnym głosem poczęcie dziewicy. Oto dlaczego w swej sprawiedliwości "myślał ją potajemnie opuścićn. Jeżliby wiedział, że to poczęcie nie pochodzi z Ducha, to byłby nielojalny, jeśliby jej nie zadenuncjował pu- blicznie. On rozumiał, że to było cudowne dzieło Boga. Poniewaz jednak dla innych było ono niezrozumiałe, uważał, że takie odesłanie będzie sprawiedliwe. W prze- ciwnym razie, gdyby zamieszkali razem, myślał, ze mo- głoby zaistnieć niebezpieczeństwo skażenia tego dzie- ła. "Myślał, aby ja odesłać", aby nie popełnić grzechu nazywania się ojceri Bożego Dziecięcia. Wzbraniai się $z$ niaz zamieszkać $z$ obawy, by nie zniestawić imienia Syna Dziewicy" 23 .

Podziwiamy tu głębokq̨ analizę Józefa sprawiedliwego ukazujacą psychologičny aspekt poślubienia Maryi.

20 Commentarii in Diatessaron 2, 11, $\operatorname{SCh} 121,71$.

21 Tauze, 21, 20, SCh 121, 385.

22 Tamże, 2, 4, SCh 121, 67.

23 Taiże, 2, 4-5, Sch 121, 67-68. 


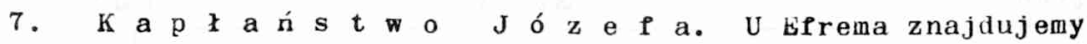
również piękne zdania na temat kapłarískiej funkcji Józefa, wyrażającej się w służeniu Jezusowi w jego okresie prenatalnyru na wzór kapłanów Starego Testamentu:

"Józef starał się służyć swemu Panu, który był w Maryi. Służył jak kapłan przed Twoją Arką Przynierza"24. $" / . . . /$ z dziesięcinami $i$ ofiara pokarmową przyprowadziz Go Józef do świątyni"25. "Dary ofiarne przyniósł z Józefem i oczyścił swoim hizopem ludzkość" 26 .

Ostatnie określenie wskazuje na udział św. Józefa w odkupieniu ludzkości, będący odkrywanyı dzisiaj cennym aspektem doktryny józefologicznej. Kapłaństwo Józefa przejawiało się w ciągłej jego obecności przy Jezusie: "Pielęgnował Józef syna jako małe dzieciz, służł mu jako Bogu, cieszył się nim jako Dobrein, drzał przed nim jak przed sprawied 1 iwym" 27 .

\section{JÓZEFOLOGIA DIONIZEGO BAR SALIBI}

Dionizy bar Șalibi / +1171/, biskup Amidy, należy do pisarzy jakobickich. Dzięki swym komentarzom do dzieł Ewagriusza, które znajdują się wiewydanych rękopisach w Berlinie ${ }^{28}$, wszedł do patrystyki. Podstawa do naszych rozważań jest jego "Komentarz do Ewangel11"29. Jego poglądy józefologiczne obejmują genealogię, zaręczyny, sprawiedliwość 1 relacje Józefa do Mary1.

1. G e $n$ e a 1 og $i$ a Dionizy podejinuje próbę wyjaśnienia genealogil Józefa odnośnie do imienia dziadka Mattana czy Mattata 30.

24 Hymni de Nativitate 16, 16, CSCO 187, 77-78.

25 Tamże, Carmina Sogyạtậa 3, 9, CSCo 187, 190.

26 Tamże, Carmina Sogyatâ $3,38, \operatorname{CSCo} 187,194$.

27 Por. Hymni de Nativitate 5, 16, CSCo 187, 41.

28 I. Ortiz de Urbina, Patrologia syriaca, Romae 1965, 220.

29 Dionysii bar Salibi commentarii in evangelia, ed. I. Sedlaček et I. B. Chabot, Lovanii 1960 - CSC0 16.

30 Tanże, $1,15, \operatorname{CSco} 16,36$. 
Mattan

Jakub

syn Mattana

wg natury

syn Jakuba

Estera

Mattat

Heli

bracia przyrodni

syn Melki

Józef

Różnicę imion między Mattanem a Mattatem Dionizy wyjaśnił następująco:

"Był mąż imieniem Mattan z pokolenia Salomona, który wziął żonę imieniem Estera 1 zrodził z niej Jakuba; po śmierci Mattana, Estera stała się żoną Mattata z pokolenia Natana. Mattat zrodził z nią Helego i Estera miała dwóch synów. Następnie Heli ożenił się i umarł bezdzietnie, a jego żonę według prawa poślubił brat Jakub, aby nie zaginęło jego imį̨. Jakub zrodził Józefa, który był synem Jakuba według natury, a Helego według prawa. Otóż Mateusz cytuje według natury a Lukasz według prawa. Dlaczego Mateusz w genealogi sięga do Salomona, Lukasz do Natana? Niektórzy mówią: Maryja, będzie pochodzić z Salomona, Józef zaś z Natana. Mateusz przedstawia pokolenia Maryi, a Lukasz Józefa"31.

Rozważania Lionizego na temat genealogii są więc, jak widać, dosyć szczegółowe i zasługują na uwagę.

2. $\quad$ a $r$ e c z y n y. Przy opisie zaręczyn Maryi z Józefem Dionizy przekazuje nam szereg szczegółów o związanych z nimi zwyczajach żydowskich:

"Zanim zeszli się znalazła się brzemienną. Był bowiem zwyczaj, aby oblubieniec z oblubienica nieszkali przez trzy lata, a potem schodzili się razem, aby się okazało, że nie pobrali się dla nieumiarkowanéj żądzy, lecz dla rodzenia. Mąż był dla kobiety pomoca i ochroną w oczach zydów, którzy widzieli ją brzemienną, przypuszczając, ze to za sprawa oblubienca $i$ nie kamienowali jej"32.

Dionizy stawia następnie pytanie: w jakim celu się zaręczali? Sam na nie odpowiada w oparciu o tradycję Ojców: "Grzegorz z Nyssy, Atanazy $i$ Jakub z Edessy głosza, że w celu kontroli i dla przepisów

31 Dionysii bar Salibi commentarii in evangelia 1, 15, CSco 16, 36. 32 Tamże, 1, 18, Csco 16, 53. 
kapłańskich, ponieważ była poświęcona /.../. Jakub ذarug zaś i św. Sewer ucza, że została zaręczona dla małżeństwa"33.

3. S p r a w 1 e d 1 i w o ść. O spranielliwości Józefa Dionizy uczył przy komentowaniu zdania z Ewangelii Mateusza /1, 19/: "Józef zaś jako mąż sprâwiedliwy nie chciał jej zniesławiać".

\begin{abstract}
"Sprawiedliwość, jak się uważa, nie wyrządza nikomu żadnej krzywdy. Kto zaś posiada jeden rodzaj sprawiedliwości, słusznie nazwany jest sprawiedliwym. Sprawiedliwość jego/Józefa/ polegała na tym, ze posiadał wszystkie cnoty. Sprawiedlifość jego była jednak sprzeczna wobec prawa, które nakazywało: "Ręka twoja uderzy w niaz pierwsza" /Pwt 13, 9/. Jego sprawiedliwość polegała na tym, że chciał ją potajemnie opuścić. Hiedział, że Dziewica jest święta albo cudzołożna. Jeżeli cudzołożna, to należało ją zdemaskować, jeżeli zaś swięta, to zatrzynać ją przy sobie. Był bowiem sprawiedliwy i miłosierny. Jego sprawiedliwość nie pozwalała, aby tolerować nierządnicę $w$ swoim domu, miłosierdzie zaś, aby ją potajemnie oddalić. Gdyby jej potajemnie nie zamierzał opuścić, nie okazałby jej miłosierdzia i zostałaby skazana na śmierć. Okazał się równiez sprawiedliwy, bo jej nie zdradził, kiedy nie znalazł u niej żadnego grzechu. Nie uważał jej za nierządnicę i jako niewinną zatrzymał ja u siebie"34.
\end{abstract}

Powołując się następnie na tradycję wyróżniał u Józefa sprawiedliwość legalną i ewangeliczną: "Mówi się o podwójnej sprawiedliwości, jedna, która oddaje każdemu według jego pracy, i druga z łaski, która winnego nie ściga, ale czyni niewinnym. Dlatego też istnieje dwojaka sprawiedliwość: jedna legalna, która oddaje "policzek za policzek", a druga ewangeliczna, która błogosławi zle czyniącemu" 35 .

4. J ó $z$ e $f$ i $M$ a $r$ y a. Dionizy podkreśla wreszcie ścisłą więź Józefa z Maryją w podejmowaniu decyzji podczas drugiego etapu ich małzeństwa, po przeprowadzeniu jej do domu oraz w trosce o nowo narodzonego Jezusa. Na uwage zasługuje tu jego komentarz do

33 Dionysii bar Şalibi commentarii in evangelia, ed. I. Sedlaček et I. B. Chabot, Lovanii 1960, CSCo 16,54.

34 Tanże, 1, 19, CSco 16, 55.

35 Tanże, $\operatorname{CSC} 016,56$. 
ewangelicznych wyrażén: "znalazła się brzemienna" 1 "zamierzał ja potajemnie opuścić":
"Józef wiedział, że była brzemienna. Myślał jednak, gdzie i w jaki sposób się to stało ? Natura kobiet jest, aby były brzemienne dzięki mężczyznom. Ona zaś stała się brzemienna bez jego udziału"36. "Pytał ja, skąd stała się brzemienna? Ona zaś odpowiedziała: z Ducha. Pozostał więc w watpliwościach, jak mówi Jakub Sarug. Jeżeli bowiem jest z Ducha, to nie przy- stol zbliżać się do niej. Jeżeli zaś z cudzołóstwa - nie przystoi łączyć swojej czystości z ciałem cudzołoż- nym. /.../. Inni mówią, ze Maryja nie usprawiedliwiała się, poniewaź wiedziała, że nie przekona go swoimi sło- wami. Rzecz bowien była cudowna. Godziło się, aby tajem- nice, którą anioł objawił, zachowała w ukryciu"37. /.../ "Józef bał się, aby nie zgrzeszyć wobec Boga zatrzymując u siebie kobletę cudzokozną, lecz anlol dodał mu sil /.... Przyjąć Maryję? Bóg ci ją przekazuje a nie jej rodzice. "Zonę Twoją" - nazywa ją żoną, aby wskazać, że nie jest cudzołoźnica. Jeżeli by taka była, nie nazwałby jej żoną. /.../. "Nie bój się jej przyjąć". Nie myśl, ze jest cudzołożnicą. Nie zblizaj sie do niej, lecz myśl, że jest brzemienna za sprawą Ducha Swiętego. Uświęć się sain, nie zblizając się do niej"38.

Dionizy ukazuje wspaniały czyn miłości Józefa wobec Maryi, kiedy przyjmuje ją za żonę: "I przyjął ją za swoją żonę $i$ nie poznał jej" Nazywa ją jego żona, aby nie zdradzié obecnego mysterium 1 nie dać powodu do podejrzeń o cudzołóstwo"39. Miłość Józefa do Maryi przejawiła się również w zorganizowaniu ucieczki do Egiptu, co Biskup Amidy opisuje następująco: "Nocą uciekali, gdyż nic nie posiadali. Nawet osła nie wynajęli za pieniądze, poniewaź Józef był ostrożny od wejścia do Jerozolimy. Inni wyjaśniają, że nie posiadali nic poza darami Magów 1 narzędzlami ciesielskimi. Maryja zaś, gdy usłyszała, wzięła dziecif w swoje raniona, wyszła pieszo na droge i upomniała Józefa, aby nabył za pieniądze osła 1 wział to, co posiadali"40.

36 Dionysii bar Șalibi commentarii in evangelia 1, 18, CSco 16, 54.

37 Tanże, 1, 19, $\operatorname{CSC} 016,56$.

38 Tamże, 1, 20, CSCO 16, 57.

39 'Tamże, 1, 24, $\operatorname{cSc} 016,62$.

40 Tanże, 2, 15, CSCO 16, 84-85. 
W bogatej spuścínnie św. Efrema dają się zauważyć równieź jego poglądy józefologiczne, htóre są wyrazem wiary ówczesnegro Kościoła syryjskiego. Diakon z Edessy ukazuje św. Józefa głównie jako męża Maryi, który będąc człowiekiem sprawiedliwym wypełniał wolę Bożą. Do osiaggnięć józefologii kfrenùwej należy zaliczyć wyjaśnienie, jak Józef i Maryja zamieszkiwali w świętości. Przez takie stwierdzenie Efrem obronił dogmat Dziewictwa Nlepokalanej i rzucí nowe światło na teologię życia rodzinnego. Podkreślił kapłaństwo ș́w. Józefa, poprzez które włącza się on w dzieło współodkupienia razem z Jezusem i Maryją. Natomiast do osiagnięć Dionizego bar Salibi należy dokładna analiza genealogii Józefa i pojęcia jego sp̣rawiedliwości. Zestawiając józefologie obydwóch autorów można wskazać na ich podobieństwa i różnice. Do podobieństw zaliczymy: $1^{0}$ komentowanie zarów. no przez Efrema, jak i Dionizego danych ewangelicznych dotyczących Maryi i Józefa; $2^{\circ}$ podkreślanie wątpliwości Józefa w chwili, gdy Maryja stała się brzemienna; $3^{0}$ ukazywanie ścisłej więzi łączącej Józefa $i$ Maryję; $4^{\circ}$ podkreślanie świętości Józefa $i$ Maryi oraz sprawiedliwość Józefa. Wóród różnic na uwagę zasługują: $1^{\circ}$ szczegółowsze zajęcie się przez Dionizego bar Salibi problemen genealogii św. Józefa; $2^{0}$ głębsze ujmowanie przez Efrema spraw życia małżéskiego Maryi 1 Józefa posługując się terminem "zamieszkali w świętości" oraz podkreślenie przezeń kapłańskich funkcji św. Józela, dzięki czemu E̊rem stał się oryginalnym teologiem.

Ks. Jerzy Woźniak CM - Kraków

LA CONCEPTION JOSEPHOLOGIQUE DE SAINT EPHRE ET DIONISIUS BAR SALIBI

/Résumé/

Saint, Éphrem qu' on apelle Docteur Marie en donnant le Commentaire evangélique nous montre la doctrine josephologique laquelle contienne des oeuvres "Commentaire sur Diatessaron", "Hymnen de Nativitąte", "Hymnęn de Ecclęsia", "Hymnen de Fide", "Carmina Nisibeng" etc. L originalite de la thélogie ephremienne souligne la saintete de la vie conjugale de Joseph et Marie. On, souligne egalement la fonction sacerdotạle de Joseph, dans cette théologie.

Evêque jacobite' Dionisius bar Salibi dans son "Commenta1re Évangélique" nous a transmis sa doctrine joséphologique. C'est qu' on montre chez lui 1 analyse de la génélogie de Joseph et la conception de la justice de Joseph. 